Спомен-парк „Крагујевачки октобар”

kjorgic@gmail.com

\title{
РОДНИ СТЕРЕОТИПИ У ОБРАЗОВАЊУ - АНАЛИЗА ОСНОВНОШКОЛСКИХ УЏБЕНИКА ИСТОРИЈЕ
}

\begin{abstract}
АПСТРАКТ: Рад се бави проблематизовањем родне неосетљивости основношколских уџбеника историје који се последњих година користе у настави, са посебним освртом на анализу родних стереотипа у њиховим садржајима. У циљу идентификовања родних стереотипа извршене су квалитативне и квантитативне анализе осам уџбеника, те је у раду указано и на основне социо-професионалне улоге у којима се женски ликови у уџбеницима најчешће јављају, њихове најчешће позитивне и негативне психо-социјалне особине, начини на којима су на илустративним материјалима у уџбеницима представљене и сл. У раду су такође представљена могућа решења која би допринела процесу деконструкције родних стереотипа у наставној пракси, а у циљу развоја и остваривања родне равноправности у друштву којем ученици припадају.
\end{abstract}

Кључне речи: родна анализа, уџбеник, историја, стереотипи.

\section{GENDER STEREOTYPES IN EDUCATION - AN ANALYSIS OF HISTORY TEXTBOOKS FOR PRIMARY SCHOOL}

ABSTRACT: The paper deals with the problem of gender insensitivity of history textbooks for primary school that have been used in teaching in recent years with a special emphasis on the analysis of gender stereotypes in their contents. In order to identify gender stereotypes, qualitative and quantitative analyses of eight textbooks have been carried out. The focus is on the main socio-professional roles in which female characters in textbooks often appear, their most positive and negative psycho-social characteristics and on the ways in which female characters are presented in illustrative materials. The paper also presents possible solutions that could help the process of gender stereotypes' deconstruction in the teaching practice, with the goal of developing and achieving gender equality in the society that the students belong to.

Key words: gender analysis, textbook, history, stereotypes.

\section{1. УВОД}

Имајући на уму улогу образовања у конструисању форми и садржаја родних идентитета, јасно је да остваривање родне равноправности, као једне од главних особина демократског друштва, није могуће без интегрисања родне перспективе у наставне планове и садржаје. Родно образовање базира се 
на праву на образовање са праведним приступом и без дискриминације. Најзначајније карактеристике родног образовања огледају се у следећем: (1) решавање родних препрека тако да свако, без обзира на пол, има једнака права на образовање, (2) поштовање различитости заснованих на роду и разумевање да род, уз старосну доб, етничку припадност, језик и религију представља део идентитета ученика/це, (3) омогућавање образовним системима да буду осетљивији према свим учесницима у процесу образовања; (4) брига да родни паритет у образовању буде део шире стратегије за унапређење родне равноправности у друштву и (5) константно развијање родног образовања како би се предупредио јаз између родног диспаритета и отклонила родна дискриминација (Foran, Virdee i Rames 2010: 8).

Када је реч о родној сензивитизацији образовања требало би споменути међународне и европске стандарде који су посвећени унапређивању родне равноправности. Хронолошки посматрано, први значајнији акт јесте Конвенција о елиминисању свих облика дискриминације жена из 1979. године (Петрушић 2007: 67-69). Са аспекта образовања, посебно су значајни чланови 5. и 10, у којима се истиче неопходност измене социјалних и културних образаца понашања мушкараца и жена у циљу елиминисања предрасуда и идеје о инфериорности/супериорности полова заснованој на стереотипним улогама мушкараца и жена (чл. 5), односно неопходност искључивања било које врсте стереотипних представа мушкараца и жена на свим нивоима образовања, која би се вршила уз ревизију наставних планова, метода и уџбеника (чл. 10) (CEDAW 1979: 1-10). Афирмацији родне сензивитизације образовања значајно је помогла и Трећа светска конференција о женама, одржана у Најробију 1985, као и обележавање Декаде жена Уједињених нација: равноправност, развој и мир (1976-1985), када је усвојена Стратегија окренута будућности. Стратегија је образовање препознала као један од кључних фактора за превладавање стереотипа о женама и унапређење њиховог свеукупног друштвеног положаја. Пекиника декларащија и Платформа за акцију (1995), усвојене на Четвртој светској конференцији о женама, истакле су за циљ што интензивније развијање образовања и обуке без дискриминације. Уведен је термин gender mainstreaming као инструмент за (ре)организацију, унапређење, развој и процену процеса креирања политика, како би перспектива родне равноправности постала саставни део на свим нивоима и у свим фазама, свих политика од стране оних који су укључени у њихово креирање (Walby 2005: 321-323).

Питањем интегрисања родне перспективе у образовање бавио се и Савет Европе, а скупштина Савета Европе донела је Препоруку о родној једнакости у образовағу, која је усвојена 1995. године. Ослонивши се на gender mainstreaming као нову стратегију деловања, у Препоруцчи 1281 (1995) усвојено је да се представе о мушкој и женској природи стичу и кроз образовање, те да образовни систем има одговорност да едукује младе за 
активно учешће у различитим аспектима демократског живота и то на свим нивоима. С обзиром да наставници/це могу бити посредници родне неравноправности, али и покретачи друштвених промена, важно је укључивање образовних институција у процес промоције родне равноправности (Recommendation 1995: 1-2). Комитет министара држава чланица Савета Европе усвојио је Препоруку CM/Rec(2007)13 о џендер мејнстримингу (gender mainstreaming) у образовању 2007. године. Ослонивши се на претходну Препоруку (1995), Савет Европе овога пута је истакао да је „образовање за демократско грађанство фактор сочијалног јединства, међусобног разумевања, интеркултуралног и међурелигијског дијалога и солидарности, да доприноси промоцији принципа равноправности између мушкараца и жена и да охрабрује успостављање хармоничних и мирних односа међу људима и са њима, као и одбрану и развој демократског друштва и културе” (Recommendation CM 2007: 1-4). Поменути документ бавио се и наставним курикулумима, напомињући да би требало обратити пажњу на родну димензију у њиховим садржајима. За овај рад је изузетно важна следећа препорука: упућен је позив за процену места које жене заузимају у наставним програмима и предметима (тачка 25). Указано је, такође, и на потребу да образовање о приватном животу буде саставни део наставних програма и да државе-чланице утичу да аутори/ауторке и издавачи наставних материјала препознају родну равноправност као важан критеријум за стварање наведених материјала (тачка 28).

\section{2. РОДНА АНАЛИЗА ОСНОВНОШКОЛСКИХ УЏБЕНИКА ИСТОРИЈЕ}

Предмет овог истраживања представља проблематизовање родне (не)осетљивости уџбеника историје у основном образовању у Републици Србији на основу резултата емпиријских истраживања. Премда је проблематика родне неједнакости у уџбеницима важна за сваки образовни систем, научна истраживања у овој области у Србији су малобројна и у самом зачетку. У циљу идентификовања родних стереотипа који се јављају у уџбеницима историје истраживање је засновано на квантитативним и квалитативним анализама уџбеника који се тренутно користе у настави из родне перспективе. Изводом из регистра одобрених уцбеника - иколска 2014/2015. година (Каталог 2014: 23-37) утврђено је да укупно 41 уџбеник историје има акредитацију (28 за основну и 13 за средњу школу). Будући да Завод за уцбенике и наставна средства има највише акредитованих уџбеника историје за поменуту школску годину (укупно 12, тј. 29,27\% од свих одобрених уџбеника, с тим да Заводови уџбеници историје чине 46,15\% од свих уџбеника који се користе у настави историје у гимназијама општег и друштвено-језичког смера) и да је оснивач истог Влада Републике Србије, одлучено је да за сваки разред основне школе буде анализиран по један Заводов уџбеник. Други уџбеник анализиран је случајним одабиром, с тим 
што постоји јасна намера да анализа обухвати издавачке куће са већим бројем издатих уџбеника историје, као што су Klett, БИГЗ и Фреска. Списак анализираних уџбеника представљен је у Табели 1 :

Квалитативно анализирајући садржаје уџбеника који се односе на жене, установљено је да се оне најчешће помињу у оквиру наставних јединица које презентују свакодневни живот људи у одређеном периоду и простору (живот у породици, одевање, исхрана и сл.), затим као жртве рата и, у уџбеницима за осми разред, у контексту борбе за једнака грађанска права. По правилу, жене се описују као јединствена друштвена група, премда се на свега неколико илустрација може уочити разлика између жена, садржаји који прате ове илустрације и, што је још значајније, садржаји уџбеника у целини не рашчлањују жене као групу већ акцентују дубоко подређен положај жена у различитим друштвима, њихове традиционалне улоге, представљајући их често са стереотипним особинама. Неки од примера су: „Девојчице су васпитаване да постану здраве мајке” (Петровић 2013: 68); „Спартанске жене су морале да буду физички јаке и строге како би рађале добре војнике” (Бркић 2011: 79); „Деца су углавном чувала стоку, мушкарци су обрађивали њиве, а жене су припремале храну и бавиле се ткањем и шивењем одеће" (Бечановић 2011: 49), итд.

\begin{tabular}{|c|c|c|c|c|c|}
\hline $\begin{array}{l}\text { Редни } \\
\text { број }\end{array}$ & Аутор & $\begin{array}{c}\text { Назив } \\
\text { ушбеника }\end{array}$ & $\begin{array}{c}\text { Место и } \\
\text { година } \\
\text { издања }\end{array}$ & Издавач & $\begin{array}{c}\text { Период } \\
\text { коришћења y } \\
\text { настави }\end{array}$ \\
\hline 1. & $\begin{array}{c}\text { Александра } \\
\text { Смирнов-Бркић }\end{array}$ & $\begin{array}{c}\text { Историја са } \\
\text { историјском } \\
\text { читанком и } \\
\text { радном свеском за } \\
\text { V разред основне } \\
\text { школе }\end{array}$ & $\begin{array}{c}\text { Београд } \\
2011 .\end{array}$ & $\begin{array}{c}\text { Завод за } \\
\text { уџбенике }\end{array}$ & $2011-$ \\
\hline 2. & $\begin{array}{c}\text { Александра } \\
\text { Петровић, } \\
\text { Весна Лучић, } \\
\text { Перуника } \\
\text { Петровић } \\
\end{array}$ & $\begin{array}{c}\text { Историја 5: } \\
\text { уџбеник историје } \\
\text { за пети разред } \\
\text { основне школе }\end{array}$ & $\begin{array}{c}\text { Београд } \\
2013 .\end{array}$ & БИГЗ & $2012-$ \\
\hline 3. & $\begin{array}{c}\text { Раде } \\
\text { Михаљчић }\end{array}$ & $\begin{array}{c}\text { Историја: за } 6 . \\
\text { разред основне } \\
\text { школе }\end{array}$ & $\begin{array}{c}\text { Београд } \\
2010 .\end{array}$ & $\begin{array}{c}\text { Завод за } \\
\text { уџбенике }\end{array}$ & $2008-$ \\
\hline 4. & $\begin{array}{l}\text { Марко Шуица, } \\
\text { Радивој Радић }\end{array}$ & $\begin{array}{c}\text { Историја: за } 6 . \\
\text { разред основне } \\
\text { школе }\end{array}$ & $\begin{array}{c}\text { Београд } \\
2010 .\end{array}$ & ФРЕСКА & $2010-$ \\
\hline 5. & $\begin{array}{c}\text { Душан } \\
\text { Батаковић }\end{array}$ & $\begin{array}{c}\text { Историја: за } 7 . \\
\text { разред основне } \\
\text { школе } \\
\end{array}$ & $\begin{array}{c}\text { Београд } \\
2010 .\end{array}$ & $\begin{array}{c}\text { Завод за } \\
\text { уџбенике }\end{array}$ & 2009 \\
\hline 6. & $\begin{array}{c}\text { Бранка } \\
\text { Бечановић, }\end{array}$ & $\begin{array}{c}\text { Историја 7: } \\
\text { уџбеник за седми }\end{array}$ & $\begin{array}{l}\text { Београд } \\
2011 .\end{array}$ & Klett & $2011-$ \\
\hline
\end{tabular}




\begin{tabular}{|c|c|c|c|c|c|}
\hline & $\begin{array}{c}\text { Јелена Јеврић, } \\
\text { Звездана } \\
\text { Петровић } \\
\end{array}$ & $\begin{array}{c}\text { разред основне } \\
\text { школе }\end{array}$ & & & \\
\hline 7. & $\begin{array}{c}\text { Ђорђе Ђурић, } \\
\text { Момчило } \\
\text { Павловић } \\
\end{array}$ & $\begin{array}{c}\text { Историја 8: за } \\
\text { осми разред } \\
\text { основне школе } \\
\end{array}$ & $\begin{array}{c}\text { Београд } \\
2010 .\end{array}$ & $\begin{array}{c}\text { Завод за } \\
\text { уџбенике }\end{array}$ & 2010 \\
\hline 8. & $\begin{array}{c}\text { Зоран } \\
\text { Павловић, Јово } \\
\text { Боснић }\end{array}$ & $\begin{array}{c}\text { Мозаик } \\
\text { прошлости 8: } \\
\text { уџбеник историје } \\
\text { за осми разред } \\
\text { основне школе }\end{array}$ & $\begin{array}{c}\text { Београд } \\
2013 .\end{array}$ & БИГЗ & $2011-$ \\
\hline
\end{tabular}

Табела 1: Списак анализираних уџбеника за основну школу издатих у периоду 20002014. године

Жене као жртве рата или цивилне жртве у ширем контексту углавном се јављају у уџбеницима за осми разред. Описујући акције аустроугарске војске у западној Србији током августа 1914. године, аутори бележе: „,(..) Аустроугарска војска је у деловима западне Србије, које је била привремено окупирала, извршила стравичне злочине над српским цивилним становништвом. Стрељано је или обешено око 4.000 стараца, жена и деце и ратних заробљеника (Ђурић 2010: 70)." Жене се помињу као жртве албанских банди на простору Косова и Метохије, али и као жртве у концентрационим логорима (Ђурић 2010: 62, 152). Приметна је чињеница да се изузетно мали број жена у уџбеницима наводи именом и презименом (уз евентуални илустративни материјал), а још је уочљивије ретко наглашавање личне делатности жена, односно њиховог доприноса заједници или друштву уопште. Насупрот томе, постоје видна и значајна одступања. Као пример може послужити Драга Машин, односно представљање српске краљице у Заводовом уџбенику за осми разред. Најпре је потребно нагласити чињеницу да, у оквиру читаве наставне теме која се односи на Србију у другој половини 19. века до 1903. године, уз илустративни материјал истакнутијих личности најчешће стоји текст који прати исти. Међутим, уз фотографију Драге Машин нема текста. Уколико анализирамо садржај у главном делу текста, добијамо информацију да је Драга „некадашња дворска дама” и „удовица”, а потом и разлоге због којих је овај брак виђен као „недостојан”:

Српска јавност, али и војска и политичка елита у Србији сматрали су да би овај брак био недостојан, јер је Драга била удовица, знатно старија од краља. Овој женидби противили су се и Александрови родитељи, краљ Милан и краљица Наталија. (...) Међутим, без обзира на свеопште противљење, краљ се венчао Драгом (Ђурић 2010: 26).

Како је на то указала Ана Столић, чија се магистарска теза тицала лика Драге Машин, у српској историографији преовладава клише према којем је Драга „неморална, бескрупулозна жена, која је крила године и није била у 
стању да подари наследника престола" (Столић 2000: 6). Аутори уџбеника определили су се за наведени клише, односно стереотипни опис лика Драге Машин, изостављајући значајне моменте: Драга је Александру пружила осећај породичне љубави и топлине које од родитеља није имао и да је ово била константа њихових односа (не Драгине амбиције), као и да преломни моменат за династију Обреновић није Александрова женидба Драгом, већ немогућност рађања престолонаследника. Ана Столић оправдано претпоставља да би незадовољство краљевом женидбом сигурно нестало, а незадовољство стањем у друштву барем утихнуло да је краљица успела да роди наследника (Столић 2000: 156-157). Овако представљена, Драга Машин остаје и код нових, млађих генерација симбол омрзнуте владавине краља Александра.

У садржајима Заводових уџбеника (ни у уџбеницима других издавача ситуација није много другачија) женски ликови остварили су апсолутну превласт у категорији чланица владарских породица. Оне су најзаступљеније као супруге и кћерке, што нимало не чуди уколико се има на уму да се најчешће и помињу у контексту склапања политичких бракова. Изузев релативно великог броја већ поменутих чланица владарских породица и књижевница, фрапантан је податак да се жене не јављају као научнице у садржајима анализираних Заводових уџбеника. Уколико жене потражимо у идентичним категоријама у уџбеницима других издавача, ситуација није битно другачија: појављује се свега неколико жена, најчешће су у питању књижевнице или уметнице (нпр. Жанка Стокић, Ана Франк) и, помало изненађујуће, Мата Хари. У сваком случају, оно што је најпроблематичније и на чему би аутори будућих уџбеника морали радити јесте управо проблем (не)присуства женских ликова у категорији образованих лица, односно научница. Тиме се ученицима индиректно шаље порука да су наука и научноистраживачки рад резервисани искључиво за мушкарце.

На основу квалитативне анализе уџбеника изведене су најчешће и најређе позитивне/негативне психо-социјалне особине мушкараца (Табела 2) и жена које се експлицитно наводе у садржајима. Анализа епитета (придева) посебно је значајна за рад, будући да верно показује какве вредносне поруке шаљу аутори уџбеника и како утичу на стварање друштвено (не)прихваћених особина на родној основи. Међутим, број придева уз имена мушких ликова далеко је већи у односу на број придева уз женске ликове.

Када су у питању придеви који стоје испред имена женских ликова, већ је указано на чињеницу да је њих далеко мање. Придеви најлепша и реформаторских способности помињу се свега два пута, док се угледна, вешта, образована, храбра и мудра помињу само једном. Дакле, благу предност ипак остварује придев којим се карактерише физички изглед жена. Негативне психо-социјалне особине жена у садржају уџбеника такође су ретке: властољубива, сурова, зла и развратна у уџбеницима се јављају само једном. Интересантна је чињеница да ни за једног мушкарца није употребљен придев развратан. Са друге стране, суровост је код мушкараца често 
позитивна особина, са аспекта њихове снаге и одважности, док је код жена експлицитно негативна.

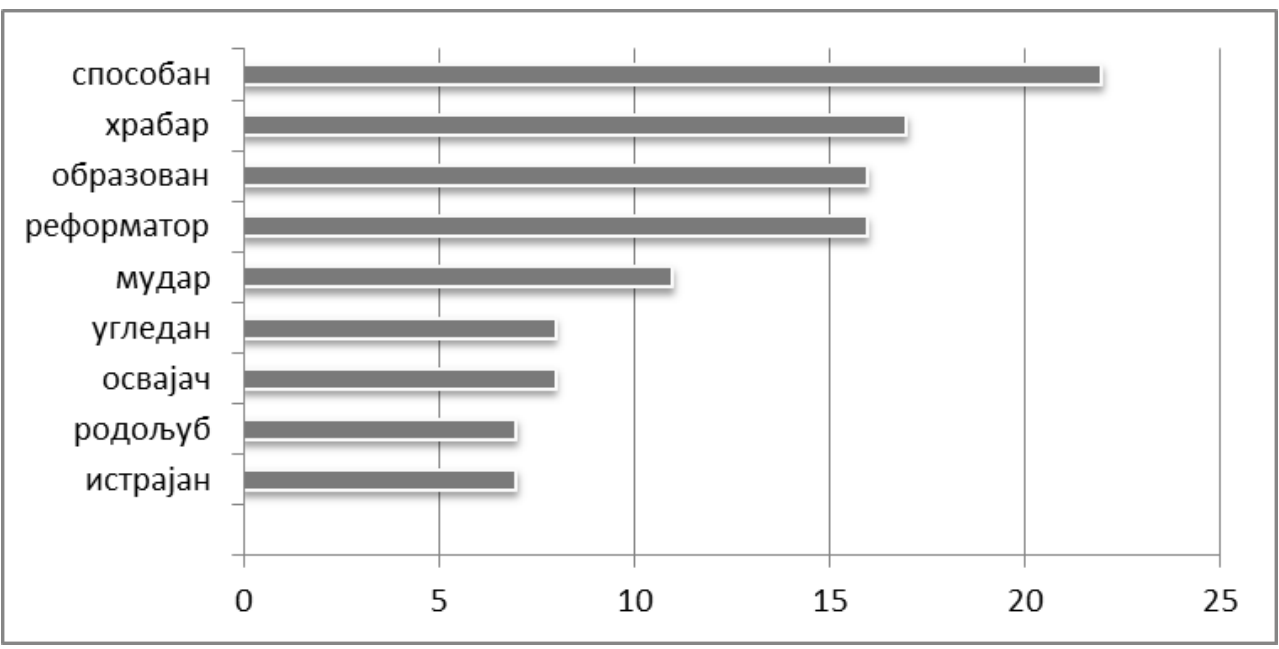

Дијаграм 1:

А) Најчешће позитивне психо-социјалне особине мушкараца у садржају уџбеника (приказано према укупном броју уџбеника у којима се појављују)

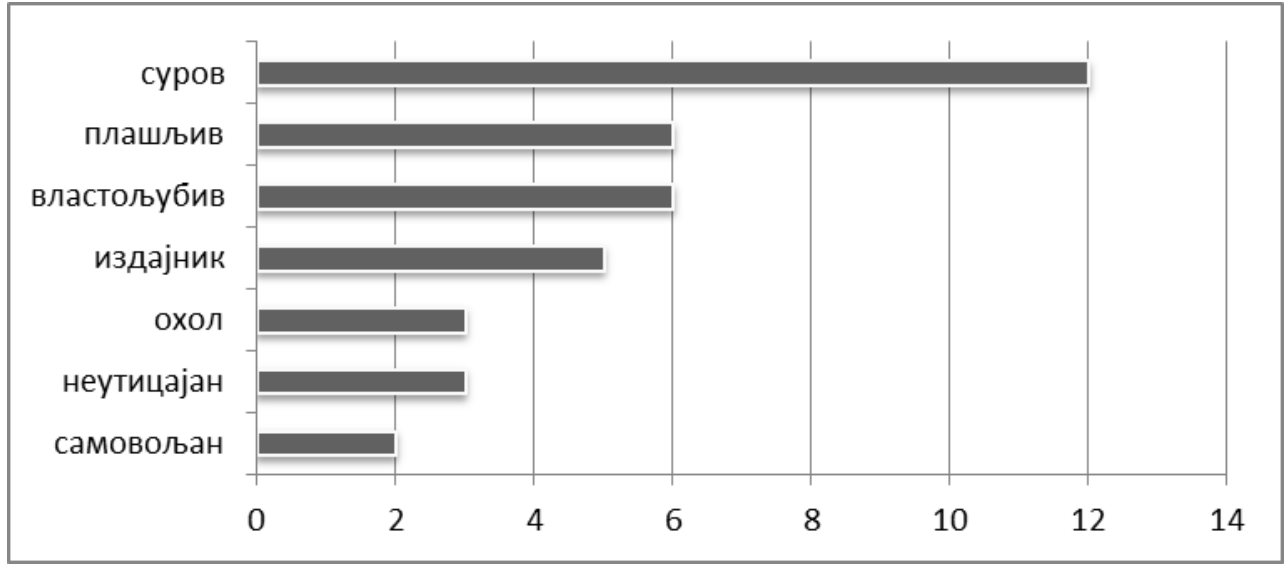

Б) Најчешће негативне психо-социјалне особине мушкараца у садржају уџбеника (приказано према укупном броју уџбеника у којима се појављују)

Анализирајући илустративни материјал одабраних уџбеника најпре долази до изражаја апсолутна превага мушких ликова. Женски ликови срећу се тек спорадично, свега неколико пута у једном уџбенику. Како би се најбоље представила доминација мушких ликова на илустративним 
материјалима, анализирано је свих осам уџбеника који су наведени у Табели 1. Уколико посебну пажњу усмеримо на уџбенике 5. разреда, будући да се у овом разреду ученици и ученице први пут срећу са наставом историје, стање са илустративним материјалом са родног аспекта није на завидном нивоу. Ако изузмемо богиње (укупно 15 у два уџбеника) и жене-митолошке или легендарне личности (укупно 4 у два уџбеника), женски ликови се јављају у искључиво две категорије - владарке (Клеопатра) и књижевнице (Сапфо). У анализираним уџбеницима долазе до изражаја стереотипне представе жена на илустративном материјалу, премда је несумњиво да намера појединих аутора и/или издавача није била таква. На пример, намера Заводовог уџбеника ауторке Александре С. Бркић јесте да се дечак и девојчица, који се налазе на насловној страни уџбеника и на страници која уводи у нову наставну тему, прикажу у функцији истраживача прошлости (историчара): дакле, да и дечак и девојчица имају активне улоге. Иако постоји неколико илустрација на којима су девојчице у активним улогама, у уџбенику преовладавају вредносно неутралне илустрације, с тим да је значајан број оних које девојчицу и дечака представљају на стереотипан начин: девојчицу у пасивној, а дечака у активној улози (Слика 1). Са друге стране, у уџбенику за 5. разред издавачке куће БИГЗ жене се такође показују у пасивним улогама (најчешће како чекају своје љубавнике) или са својим стереотипним особинама (оптерећеност физичким изгледом и одевањем) (Слика 2).

У преостала три разреда, VI, VII и VIII, женски ликови на илустрацијама доминирају у категорији чланова владарских породица - жене су приказане као супруге владара (царица Теодора, кнегиња Милица, кнегиња Љубица, краљица Наталија, Драга Машин...). Друго место према заступљености на илустрацијама заузеле су владарке (карактеристика уџбеника за седми разред, који доносе портрете Катарине Велике, Марије Терезије, Викторије), затим уметнице (Катарина Ивановић, Жанка Стокић, Надежда Петровић, Мерлин Монро) и књижевнице (Мина Караџић, Исидора Секулић, Ана Франк). У уџбеницима за шести разред и Заводовом уџбенику за седми разред жене се јављају као владарке или чланови владарских породица.

Приказане индивидуално, жене су далеко бројније у Клетовом уџбенику за седми разред. Битно је напоменути да поменути уџбеник потписују три ауторке. Међутим, женска лица су у овом уџбенику најчешће представљена у улози мајке са дететом, како обављају традиционалне женске послове или у некој другој пасивној улози. Приметно је да се у овом контексту често нарушавају стандарди квалитета уџбеника, јер текст (нпр. назив илустрације) говори једно, илустрација друго, што коначно доводи до несклада и противречности у вредносним порукама (Слика 3). Што се тиче илустрација у уџбеницима за осми разред, будући да обрађују релативно дуг временски период (од краја 19. века до грађанског рата у Југославији и демократских промена 2000. године), који је богат визуелним материјалима, у 
уџбеницима се среће само неколицина жена те ће оне овде бити посебно издвојене.

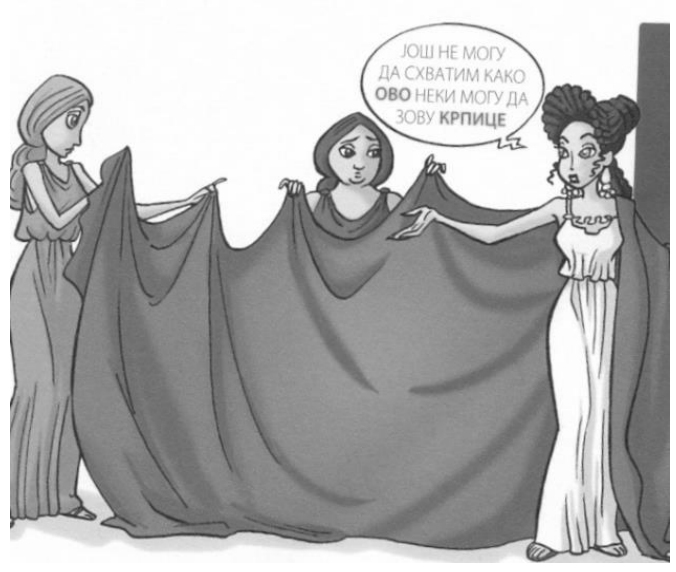

Слика 1: Дечак на коњу, девојчица га испраћа (Бркић 2011: 107)

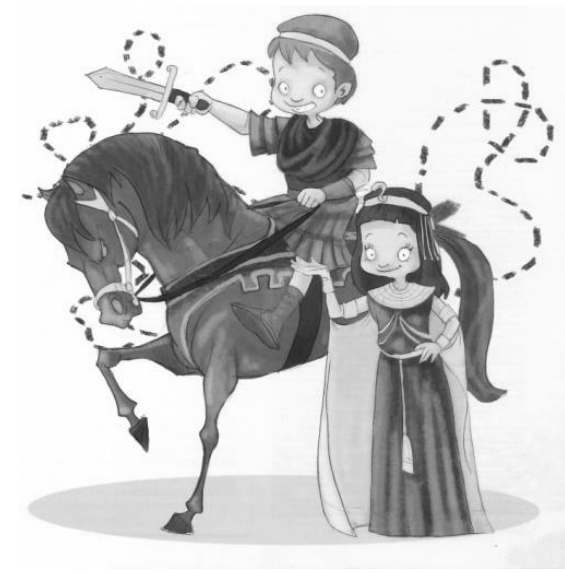

Слика 2: Римско одевање (Петровић 2013: 106)

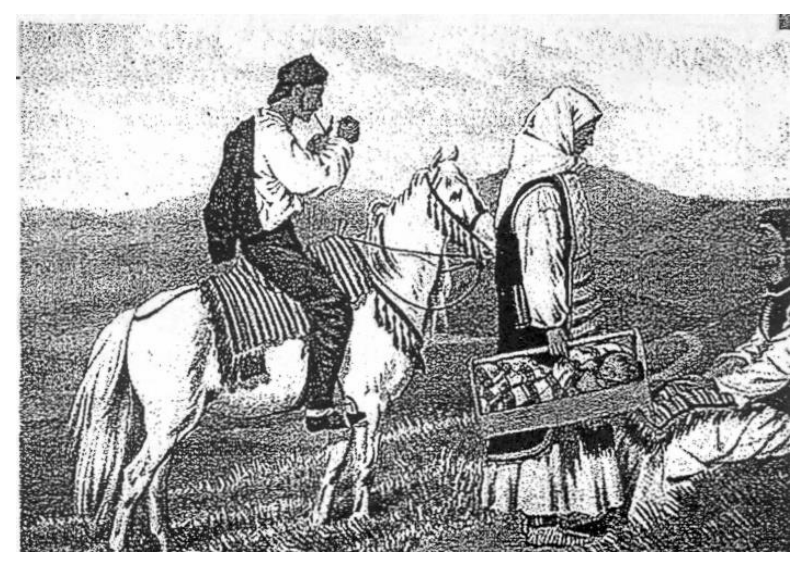

Слика 3: Српска одежда из Книна (Бечановић 2011: 69)

На уџбеничким илустрацијама налазе се самостално краљица Викторија, Драга Машин, Јелена Савојска, Мата Хари, Надежда Петровић, Мерлин Монро, Исидора Секулић, Жанка Стокић и Ана Франк, док су у оквиру владарских породица представљене Александра Романов и Марија Карађорђевић. Илустративни материјал уџбеника за 8. разред не пружа ученицима никакве информације уз илустрацију жена које представљају (нпр. Драга Машин) или представљају само основне, по правилу штуре, биографске податке (нпр. Надежда Петровић). У ситуацијама када пружају више података, аутори најчешће посежу за описом жена на стереотипан начин, с тим да су 
тада приметни и дискриминишући садржаји. Пример за последњу наведену тврдњу налази се у Заводовом уџбенику, у илустрацији и опису Мерлин Монро (Ђурић 2010: 169). Анализа конкретног материјала требало би да почне од саме фотографије; аутори су одабрали фотографију којом се истиче физички изглед М. Монро, односно њен сексипил. Јасно је да ова глумица има велики број фотографија које не истичу у први план горе поменуто, већ њен уметнички рад, свакодневни живот и сл. Уколико анализирамо садржај који прати илустрацију, требало би да уочимо одабир филмова који су прославили ову глумицу. Премда аутори нису одговорни за називе филмова, уколико се зна да се у опусу ове глумице налази преко 30 филмских остварења, питање је зашто су се аутори определили за филмове чији наслови (уз фотографију) додатно подстичу сексизам и предрасуде према групи (женама); питање је утолико битније ако се зна да је успон М. Монро отпочео улогом у филму Џунгла на асфалту, наставио се комедијом Мајмунска посла, премда су пресудан значај имали филмови Седам година верности и Неки то воле вруће. Међутим, у вредносном смислу најпроблематичнија је реченица: „Њено име везивало се за председника САД Џона Кенедија и за његовог брата Роберта Кенедија.” Што се самог садржаја тиче, наведена реченица апсолутно је недоречена и збуњујућа. Ученик/ца може само да претпоставља у ком се контексту њено име везивало за поменута лица. Проблем је још већи јер ученика овакав став аутора може навести на дедуктивно закључивање: ако је исказ А „Мерлин Монро је била америчка филмска звезда”, а исказ Б „њено име везивало се за председника САД Џона Кенедија и за његовог брата Роберта Кенедија", ученик може извући закључак да је за успех М. Монро одговорна везаност за одређене политичке кругове. Овај пример директно нарушава стандард Г14 - Недискриминащија према групама, будући да преко отворених и прикривених стереотипа аутори дискриминишу и подстичу постојање предрасуда према женама као друштвеној групи.

\section{3. ПОТЕНЦИЈАЛНА РЕШЕЬА У ПРЕВАЗИЛАЖЕЬУ РОДНИХ СТЕРЕОТИПА}

Будући да је као озбиљан проблем уџбеника историје дефинисано неприсуство жена у категорији научница и да је посебно спорна порука коју аутори и ауторке на овај начин индиректно шаљу, циљ ове препоруке је да укаже на могућа решења која би, за почетак, допринела (већој) квантитативној заступљености жена у поменутој категорији. 
Хипатија (око 355-415) прва је математичарка коју су забележили историјски извори, мада се бавила и астрономијом и филозофијом. Као дете александријског математичара и астронома упознала се са овим наукама тако да се сматра да је још у својој младости дала значајан допринос развоју геометрије, теорије бројева, астрономије... Око себе је окупљала многе образоване људе као и оне који су то желели да буду. Међутим, њено бављење филозофијом, односно њени ставови, коштали су је живота. Хришћани су је једног дана пресрели и сурово убили. Иако се чинило да су њен лик и дело потпуно заборављени, она као да је оживела у 19. веку. Од овог периода о њој се пишу песме, позоришни комади, научни радови... Недавно је снимљен филм Агора (2009), који говори управо о животу ове научнице.

Алесандра Ђилани прва је жена за коју су извори забележили да се бавила анатомијом, односно оним што данас наука сматра патологијом. Ова Италијанка радила је као асистент хирургије на Медицинском факултету при Универзитету у Болоњи. Сматра се да је њен професор, објавивши пионирски текст у овој области, заправо искористио њене идеје. Умрла је млада, највероватније од последице заразе, а њени радови су изгубљени.

Ана Фјодоровна Волкова (?-1876) била је прва жена која је дипломирала хемију 1870. године. Остала је упамћена као прва Рускиња која је постала чланица Руског друштва хемичара и, уопште, прва жена која је објавила научноистраживачки рад заснован на модерним лабораторијским испитивањима. Један од кратера на Венери носи име по овој научници.

Осим индивидуалног представљања научница, уџбеници могу понудити графички садржај на основу кога ће ученици/це стећи слику о постепеном укључивању жена у науку, као и о присуству жена у наукама појединачно, с тим да један од фактора може бити Нобелова награда.

На основу података са фотографије ученици могу закључити да је женама било потребно доста времена да стекну право на високо образовање и константно научно усавршавање. Број награђених жена Нобеловом наградом порастао је тек у последњем периоду што би значило да ученице живе у времену које женама пружа једнаке шансе за бављење науком.

$\mathrm{Ca}$ друге стране, уџбеник може понудити табеларни преглед добитница Нобелове награде по областима након чега се може закључити које научне области се и даље сматрају мушким (резервисане само за мушкарце), односно у којима су се жене избориле за равноправније учешће. Као могући 
домаћи задатак се може затражити од ученика/ца да пронађу више информација о добитницама Нобелове награде у 20. веку.

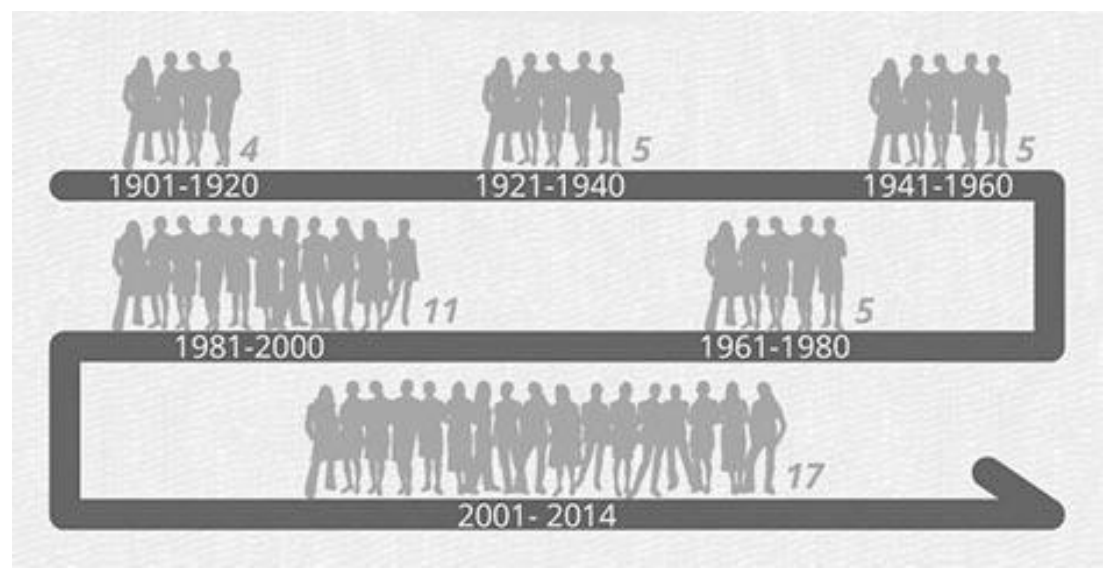

Слика 4: Жене које су освојиле Нобелову награду

Премда жене преовлађују у категорији чланова владарских породица, овакви садржаји не морају нужно бити оцењени као лоши; пример је управо искорак који је начинила Мира Радојевић у приказу лика Драге Машин. Још једна личност која несумњиво припада владарској породици, али кроз коју се могу осликати многе хумане особине (можда најзначајније љубав према брату и жртвовање за народ) јесте Оливера Лазаревић. Будући да се јавља у већини уџбеника који обрађују средњи век, могли би се представити њени биографски подаци са циљем да се ученицима покаже да нису само мушкарци велике историјске личности, које подносе жртве зарад сопственог народа.

\begin{tabular}{|c|c|}
\hline Физика & Књижевност \\
\hline 1903. Марија Кири & 1909. Селма Лагерлеф \\
\hline Марија & Грација Деледа \\
\hline Хемија & Зигрид Унсет \\
\hline 1911. Марија Кири & Перл Бак \\
\hline Ирена Жолио Кири & Габријела Мистрал \\
\hline Дороти Кроуфут Хоџкин & Нели Закс \\
\hline Ада Јонат & Надин Гордимер \\
\hline & Тони Морисон \\
\hline & Вислава Шимборска \\
\hline
\end{tabular}

Табела 2: Хронолошки паралелни преглед добитница Нобелове награде у области физике и књижевности у 20. веку 


\section{Оливера Лазаревић (око 1375-1444)}

Рођена као најмлађа кћерка кнеза Лазара и кнегиње Милице, на двору је учила читање, писање, математику и певање. Међутим, након Косовске битке, Србија ступа у вазалне односе према Османском царству, те је једна кћер кнегиње Милице морала бити послата у харем султана Бајазита. Пошто су четири кћерке већ биле удате, избора није било - једино је Оливера могла бити послата Бајазиту. Из малобројних писаних извора сазнаје се да је Оливера била једна од четири Бајазитове жене, али вероватно најутицајнија. Пренос моштију кнеза Лазара у Раваницу, као и улазак територија које су Бранковићи држали до 1398. године у састав државе потоњег деспота Стефана, управо се приписују њеном утицају на султана. Један турски извор забележио је да је Оливера Бајазиту „шапутала у братовљеву корист”. Након Бајазитове смрти, Оливера се враћа у Србију (1403), где живи повучено на двору свог брата. Последње дане највероватније је провела на двору деспота Ђурђа у Смедереву. Није имала потомака и не зна се где је сахрањена. cy:

Нека од питања уз помоћ којих можемо постићи прокламовани циљ

1. Како оцењујете значај Оливере Лазаревић за српски народ?

2. Како замишљате однос деспота Стефана Лазаревића и Оливере и њено шапутање у братовљеву корист?

3. Да ли вас њена судбина подсећа на још неке заслужне жене, којима данас не знамо ни место почивања?

Уколико историју посматрамо као друштвену науку која за циљ има да пружи одговоре о развоју људског друштва од најстаријих времена све до данашњице, са аспекта родне анализе уџбеника неприхватљиво је непостојање садржајакоји би ученицима/ученицама указали на корене одређених друштвених (не само политичких) појава. На пример, уколико је питање дискриминације жена у Србији још увек актуелно, уџбеници могу понудити садржаје који би помогли разоткривање дискриминације на конкретном примеру; ученици/це би требало да уоче да неке појаве нису само карактеристика времена у којем сами живе и да стекну преставу о томе како су се неки други људи, њима можда временски и просторно далеки, носили са појавама које и они/оне сусрећу у садашњости. Једна од тема која се такође може повезати са савременим друштвеним појавама јесте пожељност мушке деце са једне стране, односно проблем жена које партнерима не роде децу (нероткиња) са друге стране. На пример, пре две године је Савет Европе затражио од Црне Горе податке о абортусима због несразмере у броју рођене мушке и женске деце. Одломак из дела Д. Ћосића, са оживљеним личностима, требало би да укаже на дубину наведених проблема, с тим да се може 
остварити и корелација наставе историје са наставом српског језика и књижевности.

\section{Одломак из дела Корени Добрище Ћосића}

„Учиниће то због Ђорђа. За његов спас. Мора. Дижући се, придржавала се за стабло кукуруза. Једнога дана и Аћим може да каже: „Истерај, синко, ову нероткињу и узми себи другу жену.” А ја? У моравски вир! Нико неће црну мараму за мном понети. Моје дете нека наследи моје богатство. Дете ће моје бити. Кад родим, волеће ме и Аћим. Тола, Тола! Зар бољег није могла да нађе? Жена му само синове рађа. (...)

(...) „Слушај... Слободно ти живи с Толом. Мораш, чујеш ли? Ја тако хоћу. Наређујем ти! - шапутао је. — Хоћу да ми родиш сина... Наследника да ми родиш. Што ти је незгодно? (...) А Тола је јак и све га жене хоће. Досад је све мушку децу имао. И ти ћеш родити мушко. Он ће да ћути, мора, не сме ником да зине, платићу му, убићу га! Сад ја наређујем, мораш. Истераћу те из куће ако нећеш. Учини ми то. Кад те молим, еј, учини ми. Ја хоћу, ти, ти си поштена... Суђено је тако. Ви сте јаки живот да продужите, у мојој кући огњиште да се не угаси, да се не затремо..."

Питања која су од важности за схватање проблема равноправности полова, односно родне равноправности, свакако могу и морају имати своје место у курикулумима историје као наставног предмета. Једно од могућих решења је свакако адекватан садржај о феминизму.

\section{Шта је феминизам?}

Феминизам представља покрет, идеологију, лично уверење, полазну тачку у разматрању феномена који се и не морају тицати жена, скуп различитих активности чији је циљ побољшање положаја у којима се жене данас налазе. Феминизам такође представља свака жена која себе сматра феминисткињом. Јавља се у доба када се све мења - све осим положаја жена. Тако је Мери Астел у 18. веку поставила питање: „Ако се сви људи рађају слободни, како то да се све жене јављају као робиње?" Прошавши кроз сопствене успоне и падове, доживевши критике и унутар самог себе и од спољних чинилаца, судбина феминизма, односно правци његовог развоја данас се тек назиру. Основна порука феминисткиња 21. века је следећа: „,М које нисмо исте. Ми којих је много и које не желимо да будемо исте”.

\section{ЛИТЕРАТУРА}

"Convention on the Elimination of All Forms of Discrimination against Women." Pristupljeno 21.2.2018.

URL: http://www.ohchr.org/Documents/ProfessionalInterest/cedaw.pdf.

Foran, S., Virdee, G., Rames, V. (2010). Rodna ravnopravnost u obrazovanju i kroz 
obrazovanje: INEE Džepni vodič za rodnu problematiku. Ženeva: INEE.

Petrušić, N. (2007). Međunarodni i domaći pravni okvir ženskih ljudskih prava $i$ rodne ravnopravnosti: kliničko obrazovanje. Niš: Ženski istraživački centar za edukaciju i komunikaciju u Nišu.

"Recommendation CM/Rec (2007)13 of the Committee of Ministers to member states on gender mainstreaming in education." Pristupljeno 13.3.2018.

URL: https://wcd.coe.int/ViewDoc.jsp?id=1194631\&Site=CM.

"Recommendation 1281 (1955) on gender equality in education." Pristupljeno 13.3.2018.

URL:http://assembly.coe.int/mainf.asp?Link=/documents/adoptedtext/ta95/erec128 1.htm.

Walby, S. (2005). "Gender Mainstreaming: Productive Tensions in Theory and Practice", Social Politics 12(3): 321-343.

Zaharijević, A. (2008). "Kratka istorija sporova: šta je feminizam", Neko je rekao feminizam?: Kako je feminizam uticao na žene XXI veka: 368-398.

Бечановић, Б., Јеврић, Ј., Петровић, 3. (2011). Историја 7: уцбеник за седми разред основне школе. Београд: Клет.

Ђурић, Ђ., Павловић, М. (2010). Историја 8: за осми разред основне школе. Београд: Завод за уџбенике.

"Каталог уџбеника за предшколску установу и основну школу одобрених за школску 2014/2015. годину гимназија и средње стручне школе (опште образовни предмети).” Приступљено 2.3.2015.

URL: $\quad$ http://www.mpn.gov.rs/prosveta/udzbenici/skolska-2014-2015-god/1220izvod-iz-registra-odobrenih-udzbenika-skolska-2014-2015-godina

Петровић, А., Лучић, В., Петровић П. (2013). Историја 5: уцбеник историје за пети разред основне школе. Београд: Славистичко друштво Србије; Чигоја штампа.

Смирнов-Бркић, А. (2011). Историја са историјском читанком и радном свеском за V разред основне школе. Београд: Завод за уџбенике.

Столић, А. (2006). Краљица Драга. Београд: Удружење за српску повесницу.

Ћосић, Д. (1992). Корени. Београд: Београдски издавачко-графички завод. 
Kristina Jorgić

University of Novi Sad

ACIMSI, PhD student

Memorial Park "Kragujevac October"

\title{
GENDER STEREOTYPES IN EDUCATION - AN ANALYSIS OF HISTORY TEXTBOOKS FOR PRIMARY SCHOOL
}

\begin{abstract}
Summary
The paper deals with the problems of gender insensitivity of elementary school history-textbooks that have been used in recent years. The introductory part brings world and European standards that are dedicated to the promotion of gender equality with a special focus on the work of the Security Council. The qualitative and quantitative analysis are based on the research of eight history textbooks. The research shows that the textbooks' contents do not disassemble women as a group, but rather emphasize a deeply subordinated position of women in different societies, their traditional roles, often representing them with stereotypical characteristics. For example, women do not appear as scholars in most textbooks. When it comes to illustrations, women are most often represented in the role of a mother with the child or performing traditional women's roles or in some other passive role. It is noticeable that, in this context, textbook-quality-standards are often violated, because the text (for example, the description of an illustration) says one thing while the illustration says another, which ultimately leads to discrepancies and contradictions in the understanding of value messages. The last part of the paper presents possible solutions that could empower the process of gender stereotypes' deconstruction in history textbooks. It is very important that pupils recognize examples of gender inequalities in the contemporary society and bring them into line with many phenomena in the past (looking for their roots there).
\end{abstract}

Key words: gender analysis, textbook, history, stereotypes.

Примљено: 2. 5. 2018.

Прихваћено: 16. 9. 2018. 